\title{
An economic analysis of the proposed Dhaka-Chittagong Expressway in Bangladesh with the viewpoint of GHG emission reduction
}

\author{
Md. Zia Uddin ${ }^{1} \cdot$ Takeshi Mizunoya $^{2}$ (D)
}

Received: 29 August 2018 / Accepted: 10 September 2019 / Published online: 26 September 2019

(c) The Author(s) 2019, corrected publication 2019

\begin{abstract}
Frequent road intersections in Dhaka-Chittagong National Highway (NH1), the major transport corridor of Bangladesh, significantly reduce the level of service of the corridor and eventually leads to inefficient fuel economy and excessive greenhouse gas (GHG) emission. In spite of upgrading NH1 into a four-lane highway, major road intersections reduce vehicle speed and increase congestion time and eventually burn fuel. Fuel expenses during this lost time cover no distance but increase vehicular emission within the vicinity of road and contribute to roadside temperature. Besides, the transport sector's energy demand in Bangladesh is supported mostly by imported fuel that drains out foreign currency and inhibits GDP growth. Against the backdrop, the Government of Bangladesh is proposing to construct a four-lane expressway. The paper attempts to estimate the fuel loss savings, GHG emission reduction and economic benefit of constructing Dhaka-Chittagong Expressway. As the construction of the expressway paved a way for an increment of traffic growth by $10 \%$, the study infers that the average lost time because of 36 intersections for a projected annual average daily traffic of 27,334 vehicles/day (in 2022). In addition to that, the fuel loss savings for various vehicle classes affect economic growth and the ensuing idling emission of EFI and MFI engines contributes to transport sector pollution. The study intends to expedite the fact that Dhaka-Chittagong Expressway would not only replace road interventions that reduce travel time cost, expenditures regarding vehicle operating and accident but also contributes cardinally to economic emancipation of the country. The estimated Benefit-Cost Ratio (BCR) was 1.23, net present value was 762.34 Million USD) and Economic Internal Rate of return was $18.27 \%$ of the proposed project.
\end{abstract}

Keywords Fuel consumption - Greenhouse gas emission - Vehicle operating cost . Travel time cost · Cost-benefit analysis - Expressway construction

Takeshi Mizunoya

mizunoya.takeshi.ff@u.tsukuba.ac.jp

Extended author information available on the last page of the article 
JEL Classification Q51 - Q58 · R41 · R42

\section{Introduction}

\subsection{Background of the research}

Motorization-development-urbanization is a steadily increasing phenomenon that is observed in many developing countries like Bangladesh. Since there are growing changes in transport sector aiming at enhancing connectivity across countries, the dependence on energy sources based on fossil fuel has increased rapidly in recent years and as a result greenhouse gas (GHG) emissions have also increased. On this backdrop, the Government of Bangladesh is pursuing an environment-friendly sustainable transport system to implement National Integrated Multimodal Transport Policy, 2013, which clearly spells out, "Future planning or transport sector must, therefore, ensure that the system is sustainable and environment friendly in the long run". Among the major road corridors in Bangladesh, the Dhaka-Chittagong National Highway (NH1) is one of the most important economic corridors in terms of passenger and freight movement. 92\% of country's total trade (export and import) and $81 \%$ of National Ready-Made Garments (RMG) is transported by this highway with very few alternatives available. Besides, the corridor offers great potential for regional connectivity with neighboring countries, India and Myanmar. In spite of improving NH1 to four lanes to meet the forecasted traffic demand, the existing road network is failing to deliver the desired Level of Services (LOS). The number of motorized vehicles is expected to grow to at least 35,000 per day in 2020, 70,000 in 2030 , and more than 120,000 in 2040, depending on the section and selected scenario for the traffic forecast (Asian Development Bank (ADB) 2012). This forecast indicates a growing traffic demand for this corridor which is alarming for utilization of this corridor in future. In spite of four lanes, the $230.0-\mathrm{km}$ journey between the capital city Dhaka and the port city Chittagong would take on average $7.0 \mathrm{~h}$ because of congestion on the road, resulting from frequent interventions against the traffic flow.

\subsection{Objectives of the research}

Starting from Dhaka, there are more than forty major intersections along the national highway, up to Chittagong. The major traffic hotspots on NH1 are located at Katchpur, Madanpur, Daudkandi, Madhaiya, Comilla Cantonment, Padua Bazar, Biswa Road Intersection (Comilla), Uttar Krishnapur, Feni and Baraiyarhat (Fig. 1). However, a vehicle running on this highway has to come across instances of unauthorized market places and feeder roads, interference of slow-moving vehicles frequently, and hence, finding no other way, the vehicle cuts its speed gradually.

At every intersection, the vehicle's speed is steeps and the vehicle remains stopped at the traffic signal till the green sign is turned on. When the vehicle stops at an intersection, the engine runs but the vehicle does not move an inch. The 


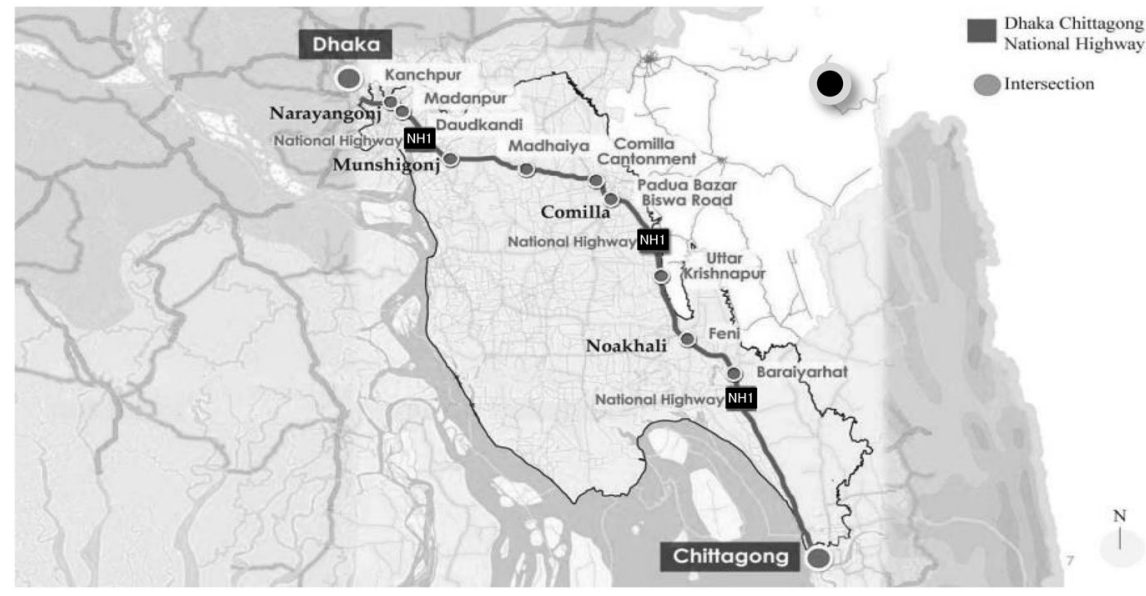

Fig. 1 Layout of Dhaka-Chittagong National Highway (Source: Ministry of Road Transport and Bridges (MoRTB) 2015a)

burning of fuel during this time becomes wastage and this emission creates negative impacts afterwards. In case of NH1, due to high traffic density, the vehicular emission of $\mathrm{CO} x, \mathrm{NO} x, \mathrm{SO} x$ is comparatively higher within the surrounding areas of the road and beyond the region than the corridors of low traffic density. The proposed Dhaka-Chittagong Expressway is supposed to render an alternative to the existing situation. It promises safer, faster and environment-friendly passenger and freight transportation as well as it wills to foster economic growth of the country. The main purpose of the research is

a) To estimate the amount of time loss and fuel loss for each vehicle at the major intersections on the existing Dhaka-Chittagong National Highway.

b) To estimate the amount of GHG emission reduction and it's social cost after replacing the major intersections by Dhaka-Chittagong Expressway.

c) To estimate the reduction of accident cost, travel time cost, and vehicle operating cost after replacing the major intersections by Dhaka-Chittagong Expressway.

d) To estimate the amount of toll collection from Dhaka-Chittagong Expressway.

e) To evaluate the economic viability of the proposed Dhaka-Chittagong Expressway in terms of environmental and economic aspect and to evaluate the validity of the expressway construction.

Actually, economic effects of the public investment include not only direct effects but also indirect effects. Kohno (2016) defined the categories of "generation-basis" and "incidence-basis" economic effects in addition to the categories of direct and indirect economic effects of the public investment, and shows the necessity of measuring the incidence-basis indirect economic effects of public investment. In that book, the author summarizes economic effects of expressway in detail as shown in Tables 1 and 2. In this study, while recognizing the importance of measuring indirect effects, to simplify the evaluation, we focus only on the direct effects such as 


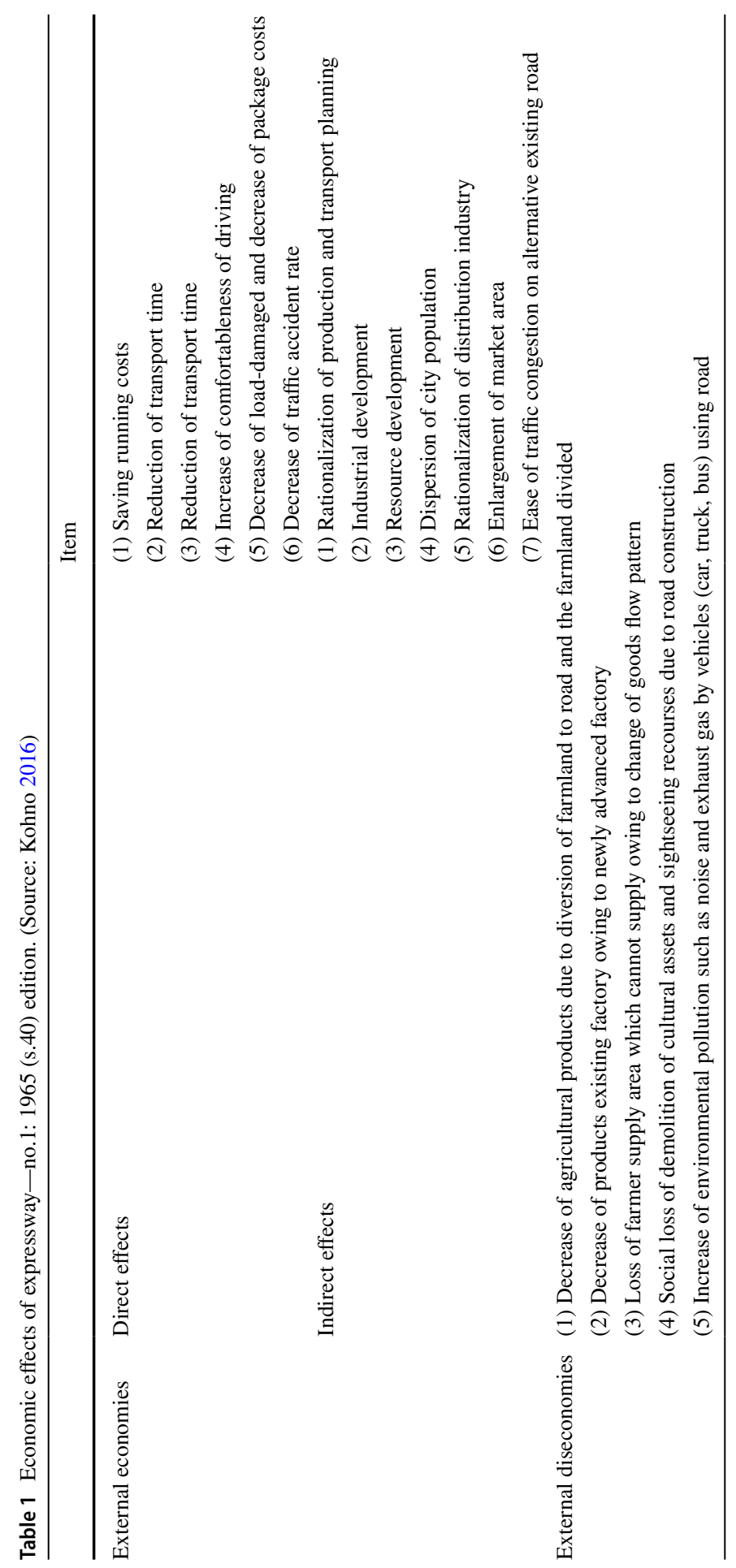




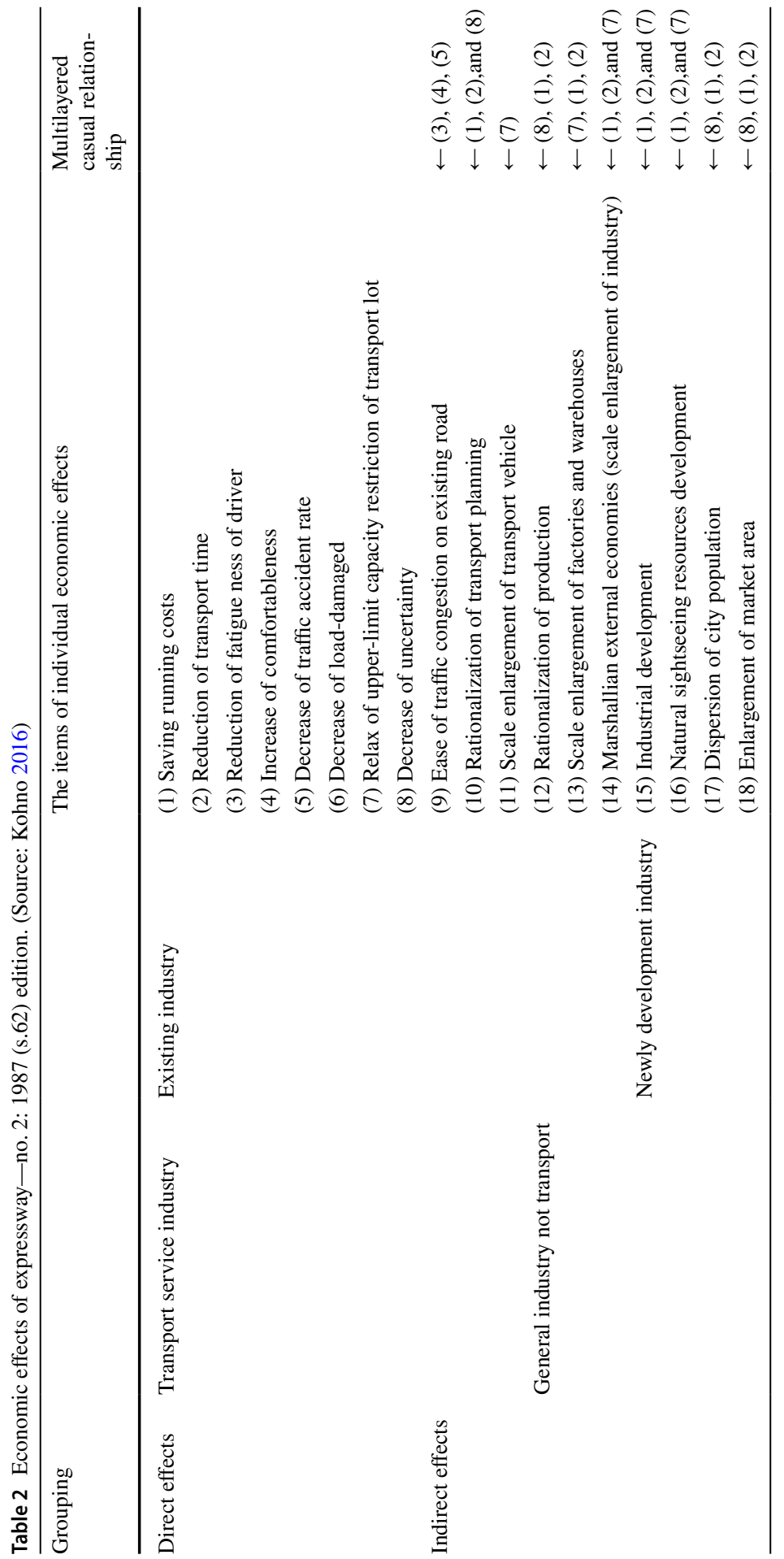


fuel savings, GHG emission savings, accident cost savings, vehicle operating cost saving, travel time cost savings and toll collection amount of the government which related to (1), (2) and (6) in Table 1, and (1), (2) and (5) in Table 2. We would like to emphasize that we analyzed the possibility of GHG emission "saving", not GHG emission "increment" by the highway construction. This is thought to be a unique phenomenon in developing countries where traffic congestion is chronic. We show that highway construction in developing countries can generate a positive impact on the environment rather than a negative one in this research.

We will also analyze indirect effect considering "generation-basis" and "incidence-basis" economic effects argued in Kohno (2016) and make a more comprehensive evaluation in near future research.

\subsection{Prospects of Dhaka-Chittagong Expressway}

The 217.0-km-long Dhaka-Chittagong Expressway is proposed to have four-lane carriageways with two additional service lanes for non-motorized vehicles. Connecting the capital city Dhaka to the port city Chittagong, the corridor passes through five chief districts Narayangonj, Munshigonj, Comilla, Feni and Noakhali (Fig. 1). The proposed expressway will provide enough additional capacity in this vital corridor to accommodate future traffic growth and will also meet the demand for a safer and more reliable road connection. The port city Chittagong has multifaceted local and regional potential geo-economic prominence. The Chittagong port will be linked with a number of Government and Private owned under construction and proposed Economic Zones (4 in Chittagong, 1 in Comilla, 1 in Munshigonj, 3 in Narayangonj and 9 in Cox's Bazar) (Bangladesh Economic Zones Authority (BEZA) 2017). The southern part of Chittagong is being developed into a prospective energy hub and JICA-financed Matarbari deep seaport will be established near Cox's Bazaar that will engender huge freight movement on this corridor. Beyond local potentiality, the highway is also a vital portion of the Asian Highway (AH41). Again, through proposed Bangladesh, China, India, and Myanmar (BCIM) and Bangladesh, Bhutan, India, and Nepal (BBIN) regional connecting routes, Assam, Sikkim, Tripura, Mizoram, and Manipur areas in India together with China, Nepal, and Bhutan have expressed deep and significant interest in using the port of Chittagong. In this regard, an expressway connection between the capital and the port is essential for the future infrastructural development of the country and to tie in with the anticipated international counterparts.

\section{Literature review}

\subsection{Traffic pattern of Dhaka-Chittagong National Highway}

The traffic growth pattern of Dhaka-Chittagong National Highway (NH1) is completely distinguishable compared to the other national or regional highways in Bangladesh. Bi-directional traffic on this corridor portrays an increasing trend 


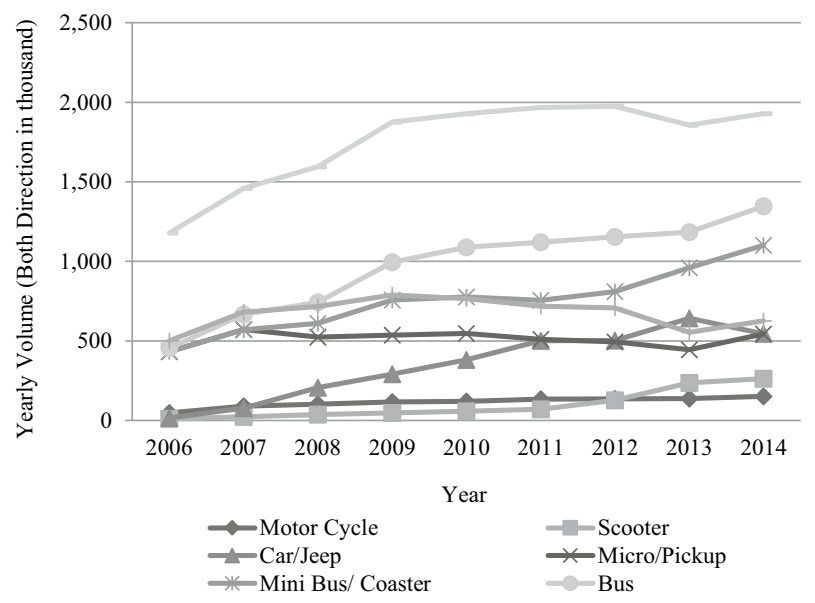

Fig. 2 Vehicle classwise yearly traffic growth on NH1 (Source: Ullah et al. 2016)

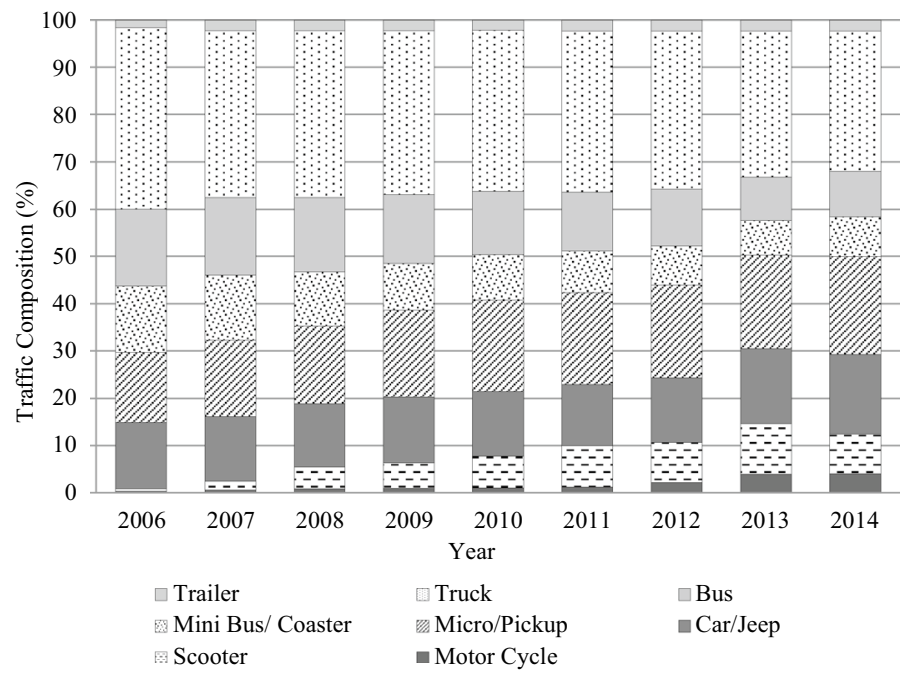

Fig. 3 Traffic composition of NH1 (in percentage of the total traffic) (Source: Ullah et al. 2016)

(Fig. 2). Ullah et al. (2013) evaluated different growth factors for different vehicle classes. Analyzing the vehicle composition found in this highway, Ullah et al. (2016) showed trucks were the predominant class and were significant, resulting in increased growth rate and topmost proportion in the traffic flow (Fig. 3). From transportation application standpoint, truck and bus volumes signify roadway capacity and influence road safety operations. These heavy vehicles show lower response during application of brake and acceleration compared to lightweight passenger cars or microbus. Therefore, vehicle size, weight and speed control the traffic operations 
behavior during mix traffic conditions which eventually leads to inefficiency of the mobility on the corridor. Based on the traffic data obtained from time to time during 2006-2014 on this corridor, medium and heavy trucks comprised an average of 39\% of the total average motorized traffic (Ullah et al. 2016).

\subsection{Fuel consumption and emission in the transport sector}

Transport sector is a voracious consumer of energy in Bangladesh. With the demand for transport sector multiplying annually, consumption of energy in this sector also grew in recent years parallel to the average GDP growth (Alam et al. 2013). This energy demand is mitigated mostly by imported fuel that drains out foreign currency and eventually hinders GDP growth. In spite of Government's initiatives for switching to compressed natural gas (CNG), during the period 1999-2003, CNG driven cars have faced an accretion only from 4.59 to $4.62 \%$ per annum, while the demand for petroleum products increased $5.09 \%$ during the same period in transportation sector (Bangladesh Petroleum Corporation (BPC) 2008). Under business-as-usual (BAU) scenario, the projected fuel demand in Road sector is supposed to increase from 50 trillion BTU in 2004 to 220 trillion BTU by 2020 and about 440 trillion BTU by 2030. Particularly, diesel demand is expected to increase from 1.2 Mtoe in 2005 to 4.0 Mtoe by 2020 and more than 8.0 Mtoe by 2030 (Alam et al. 2013). Bangladesh imported 3.6 million ton of petroleum fuel in 2009 that cost US \$1.99 billion (1.96\% of total GDP and 16\% of current account balance) (Alam et al. 2013).

The sector-wise $\mathrm{CO}_{2}$ contribution in Bangladesh is 14\% (Climatelinks, 2016). Lenzen (1999) mentioned that vehicle fuel consumption is responsible for $75 \%$ of the energy consumed and GHG emissions produced during the life cycle of a road. The remaining $25 \%$ corresponds to the construction and maintenance of vehicles and infrastructure. The current study will focus on $\mathrm{CO}_{2}, \mathrm{CH}_{4}, \mathrm{NO}_{x}, \mathrm{HC}$ and $\mathrm{CO}$ emission.

\subsection{Factors affecting vehicular emission}

Guensler (1993) categorizes vehicle emissions factors based on vehicle specifications (class, type, model year, technology, total weight, engine capacity, fuel consumption mechanism, emission control technology, mileage, computerized onboard diagnostic system), fuel specifications (type, content and composition, physical and chemical properties, dissolved oxygen quantity, viscosity and volatility of fuel, hydrocarbons content), vehicle operating conditions, and vehicle operating environment. Vehicle emissions are higher for older vehicles (Pollack and Heiken 1992; Rouphail 2000; Calvert et al. 1993; Barth and Norbeck 1997). Fuel composition and physicochemical properties influence vehicle emissions (Calvert et al. 1993; Guensler 1993).

Driver behavior predominantly changes vehicle emissions since it affects the frequency and magnitude of enrichment events. Aggressive driving causes significantly higher emissions (Transportation Research Board (TRB) 1995; Shih et al. 1997; Shih and Sawyer 1996; LeBlanc et al. 1994). Recent studies also revealed a 
road-grade relationship with speed and acceleration (Bachman 1998). De Vlieger (1997) and De Vlieger et al. (2000) used instrumented vehicles to demonstrate that aggressive driving resulted in a sharp increase in fuel consumption (12-40\%) and emissions (1-8 times) compared to normal driving. For volatile organic components (VOCs) and $\mathrm{NO}_{x}$, aggressive driving increases emissions ranging from $15-400 \%$ to $20-150 \%$, respectively.

During the occasions of traffic jam, while driving through the urban city blocks or in parking area heavy-duty diesel vehicles remain idling and consume more fuel and cause emission, referred as vehicle idling. Based on 75 heavy-duty diesel engines and trucks, Khan et al. , (2006) reported idling emission rates for electronic fuel ignition (EFI Model Year 1989-2005) and mechanical fuel ignition (MFI Model Year 1969-1994) engine-installed vehicles and found that emission for EFI engine is less than MFI engine. Since there are MFI engine vehicles are being used in Bangladesh, during vehicle idling time, wastage of the fuel from MFI vehicles are significant for higher fleet over the year.

\subsection{Road accident scenario and costs}

In Bangladesh, the complexities and fatalities related to Road mishaps could well be 20,038 each year (WHO 2009). In terms of vehicle ownership, Bangladesh has one of the highest fatality rate internationally, over 100 deaths per 10,000 motor vehicles. About $70 \%$ of road accident fatalities occurred in rural areas of which nearly 50\% occurred on national and regional highways. Accidents are highly clustered which implies that most of the road calamities tend to occur at some particular spots, nearly $50 \%$ of accidents on less than $5 \%$ of the highway network. Predominant accident types are hit pedestrian (45\%), rear end (16.5\%), head on (13.2\%) and loss control/overturning (9.3\%) (Hoque and Mahmud 2015). The feasibility study conducted under The Roads and Highways Department (RHD) mentioned a figure of 41 accidents per 100 million vehicle-km was found in a 2013 report that covered part of the Kanchpur-Daudkandi section (Japan International Cooperation Agency (JICA) 2013). This is a busier section than National Highway NH1 as a whole, and the project has obtained a lower value of 25 accidents per vehicle-km for National Highway $\mathrm{NH} 1$ as a whole, of which two are fatal and 13 are serious. For the expressway, these values are assumed to be halved, which would be in line with international experience (Ministry of Road Transport and Bridges (MoRTB) 2015a).

RHD Road User Cost 2016-2017 report has adopted net lost output method to calculate an approximate cost of accident. This report classified accident cost into main five cardinal components (a) lost output (loss to the economy of productive capacity of the person), (b) medical cost (first aid, rescue services, rehabilitation cost), (c) human cost (pain, grief and sufferings, funeral cost), (d) vehicle damage cost (repair, lost economic output, towing cost) and (e) administration cost (police investigation, legal cost, insurance administration and accident spot cleansing). Depending on the types and severity of accident [fatal road traffic accident (RTA), grievous RTA, simple RTA and property damage only (PDO)], RHD Road User Cost 2016-2017 has calculated average cost per accident. This report did not study 
costs related to road property damage and travel time loss from the road blockades create after the accident (Ministry of Communications (MoC) 2005).

\section{Methodology}

\subsection{Data collection for research}

The traffic data and fuel efficiency information used in this study are extracted from secondary source like published journals (e.g., International Journal of Environmental Science and Technology, Journal of Atmospheric Environment, Journal of Air Waste Manage Association), national (e.g., Ministry of Communications, Ministry of Road Transport and Bridges, Bangladesh Economic Zones Authority, Bangladesh Petroleum Corporation) and international websites (e.g., Japan International Cooperation Agency, Asian Development Bank, World Bank, Transportation Research Board, International Energy Agency) (References). In addition to that, the study derived and gathered major information support from 'RHD Road User Cost 2004-2005 report', 'Draft RHD Road User Cost 2016-2017 report', 'Toll Policy, 2014' and Report on 'Feasibility Study and Detailed Design under Technical Assistance for Detailed Study and Design of Dhaka-Chittagong Expressway on PPP Basis' published by Roads and Highways Department, Bangladesh. The theory applied in the study (Eqs. 1-18) was based on Transportation Research Board (TRB) (2000) and Wright (1995).

According to the RHD Road User Cost 2016-2017 report, the total traffic is divided into eight classes considering vehicle size and capacity which are class 1: motor cycle $(4.03 \%)$, class 2 : scooter $(8.39 \%)$, class 3: car/jeep $(16.94 \%)$, class 4 : micro/pickup (20.69\%), class 5: minibus $(8.34 \%)$, class 6 : bus $(9.62 \%)$, class 7 : truck $(29.67 \%)$, class 8 : trailer $(2.32 \%)$ and class 9: toll free (vehicle compositions are shown). The study has computed the average bi-directional traffic growth rate $(10.30 \%)$ on this passage during 2006-2014 (Table 3). For traffic projection till 2051, based on the data available in 2014 (base year), the study applies HDM (Highway Development and Management) software generated traffic growth projection. HDM software used annual traffic growth forecasts from traffic survey and analysis report of March 2015. The report cited the progression of passenger and freight traffic during 2014-2020 as 3.0\% and 6.1\%, during 2020-2030 as 5.99\% and $4.5 \%$ and from 2030 and afterwards as $5.32 \%$ and $4.0 \%$, respectively. The traffic composition of 2022 is considered as the base year traffic composition that is applied for this research. The projected annual average daily traffic (AADT) is estimated as 27,433 Veh/day.

After survey done under the feasibility study, it is predicted that the market share by the expressway would be $58 \%$ in 2022 (the project will be opened by rendering access to the common mass) and afterwards (Ministry of Road Transport and Bridges (MoRTB) 2015a). Dhaka-Chittagong National Highway is aligned mostly on the flat terrain and in this study, the road surface is considered as wet condition $(f=0.33)$ to assume friction developed between vehicle's tire and road surface. The existing alignment terrain of this highway is flat in most of 
Table 3 Yearly traffic growth rate on Dhaka-Chittagong National Highway

\begin{tabular}{llcl}
\hline Year & $\begin{array}{l}\text { Total yearly volume } \\
\text { (bi-direction) }\end{array}$ & Growth rate & $\begin{array}{l}\text { Average } \\
\text { growth } \\
\text { rate } \\
\%\end{array}$ \\
\hline 2006 & $3,072,600$ & $\%$ & 10.30 \\
2007 & $4,136,078$ & 34.59 & \\
2008 & $4,531,753$ & 9.56 & \\
2009 & $5,405,055$ & 19.26 & \\
2010 & $5,662,910$ & 4.77 & \\
2011 & $5,775,131$ & 1.98 & \\
2012 & $5,904,938$ & 2.25 & \\
2013 & $6,014,954$ & 1.86 & \\
2014 & $6,503,300$ & 8.12 & \\
\hline
\end{tabular}

Source: Ullah et al. 2016 and the author has calculated average growth rate

the cases except a few undulations. Since safe stopping distances on upgrades are shorter and on downgrades are longer, in this study, the percentage of Grade $(G)$ is neglected $(G=0)$ for simplification. Due to mixed traffic, the nominal velocity is considered as $100.0 \mathrm{kmph}$ for free-flow condition at the expressway. Transportation Research Board (TRB) (2000) mentioned vehicle acceleration and deceleration rates to be factors in fuel economy, travel time values and estimating how normal traffic flow is resumed after a breakdown. Vehicle acceleration rates of passenger cars accelerating after a stop range between 1 and $4 \mathrm{~m} / \mathrm{s}^{2}$, while passenger car deceleration rates vary between 2 and $8 \mathrm{~m} / \mathrm{s}^{2}$ (Transportation Research Board (TRB) 2000). As declared in the literature review, vehicular emission depends on a number of factors. When the 'Red Signal' is on, the vehicle remains in 'Idling condition', the engine runs but the vehicle remains as it is with no sign of movement. Emission factors (EFs) are quoted from Frey et al. (2001) for driving condition and Khan et al. (2006) for engine idling.

\subsection{Methods, formula and data analysis}

Expressway projects or regional corridor development projects usually adds similar benefit factors. In every roadway project, travel time, vehicle operating cost savings and safety issues consume primary attention and benefits are derived from all those components. Particularly, in the study, fuel consumption reduction and social cost of emission savings are incorporated as benefit components. The income from toll collection will also add benefit to the project. The toll generated income will compensate the investment and reduce the risk of Government Equity Share (Ministry of Road Transport and Bridges (MoRTB) 2015a). 


\subsubsection{Calculation of loss time at an intersection}

At an intersection, when the 'Red Signal' is turned on, the driver needs perception reaction time $(2.5 \mathrm{~s})$ before applying the brake. The driver decelerates the vehicle and stops before the stopping line at the intersection. The vehicle remains stopped till the 'Green Signal' is turned on and then the driver applies the acceleration to the vehicle to attain the optimum speed. When there is a long queue, after the first vehicle arrives at the stopping line, the second vehicle goes through headway that creates a congestion loss time for the vehicles waiting at the intersection. A vehicle needs more travel time compared to a non-signalized intersection due to perception reaction time, deceleration time, stopping time, congestion loss time and acceleration time. The delay becomes more crucial for a busy highway, when frequent intersections, roadside interferences, as well as slow-moving vehicles (SMVs) and non-motorized vehicles (NMTs) interrupt flow that eventually reduces the roadway's desired Level of Services (LOS). The loss times have been calculated by solving the following equations (Eqs. 1-18) (Wright 1995):

a) Vehicle at deceleration phase:

$$
t_{\mathrm{d}}=t_{\mathrm{p}}+t_{f}
$$

in which $t_{\mathrm{d}}$ deceleration time, $t_{\mathrm{p}}$ perception reaction time, and $t_{f}$ deceleration time due to friction.

$$
d_{\mathrm{p}}=t_{\mathrm{p}} \times v
$$

in which $d_{\mathrm{p}}$ distance covered during perception reaction time, $t_{\mathrm{p}}$ perception reaction time, and $v$ vehicle speed.

$$
d_{f}=\frac{V^{2}}{254(f \pm G)}
$$

in which $d_{f}$ distance covered during deceleration due to friction, $V$ vehicle speed in kmph, $f$ coefficient of friction between tires and roadway, and Ggrade.

$$
a=\frac{v^{2}-u^{2}}{2 d_{f}},
$$

in which $a$ deceleration, $v$ vehicle final speed, $u$ vehicle current speed, and $d_{f}$ distance covered during deceleration due to friction.

$$
t_{f}=\frac{v}{a},
$$

in which $t_{f}$ deceleration time due to friction, $a$ deceleration, and $v$ vehicle speed.

b) Vehicle at stopping phase:

$$
t_{\mathrm{s}}=\mathrm{Tc}-\mathrm{Tg},
$$

in which $t_{s}$ stopping time, Tc total cycle time, and Tg total green time.

$$
\mathrm{DDHV}=\mathrm{AADT} \times k \times D,
$$


in which DDHV directional design hourly volume, AADT annual average daily traffic, $k$ peak hour factor ( $k=0.12$ for sub-urban area), and $D$ peak direction factor $(D=0.6)$.

$$
s=\frac{3600}{\mathrm{~h}},
$$

in which $s$ saturated flow (in h) and $h$ headway (in s).

$$
c=s \times N \times \frac{g}{C},
$$

in which $c$ capacity of lane group, $s$ saturated flow, $N$ number of lane in one direction, and $\frac{g}{C}$ effective green time to cycle time ratio.

$$
V=\frac{\mathrm{DDHV}}{6},
$$

in which $V$ volume of lane and DDHV directional design hourly volume.

$$
X=\frac{V}{c},
$$

in which $X$ volume to capacity ratio of lane group, $V$ volume of lane, and $c$ capacity of lane group.

$$
t_{i}=900 \times T \times\left\{(X-1)+\sqrt{(X-1)^{2}+\frac{8 k l X}{c T}}\right\},
$$

in which $t_{i}$ incremental delay, $X$ volume to capacity ratio of lane group, $k$ signal control adjustment factor, $l$ upstream filtering adjustment factor, $c$ capacity of lane group, and $T$ time period $\left(T_{\text {peak }}=3.0 \mathrm{~h}, T_{\text {off_peak }}=21.0 \mathrm{~h}\right)$.

c) Vehicle at acceleration phase:

$$
t_{a}=\frac{v}{a}
$$

in which $t_{a}$ acceleration time, $a$ acceleration, and $v$ vehicle speed.

$$
t=t_{d}+t_{s}+t_{i}+t_{a}
$$

in which $t$ total time, $t_{d}$ deceleration time, $t_{s}$ stopping time, $t_{i}$ incremental delay, and $t_{a}$ acceleration time.

$$
d_{a}=u t_{a}+\frac{1}{2} a t_{a}^{2}
$$

in which $d_{a}$ distance covered during acceleration, $u$ vehicle current speed, and $t_{a}$ acceleration time.

$$
d=d_{p}+d_{\mathrm{f}}+d_{a}
$$


in which $d$ total distance covered during perception reaction time, deceleration time due to and acceleration time; $d_{p}$ distance covered during perception reaction time; $d_{\mathrm{f}}$ distance covered during brake due to friction; $d_{a}$ distance covered during acceleration.

$$
v=\frac{d}{t_{x}},
$$

in which $v$ vehicle's average speed; $d$ total distance covered during perception reaction time, deceleration time due to and acceleration time; $t_{x}$ time required for no intersection scenario.

$$
t_{\text {loss }}=t-t_{x},
$$

in which $t_{\text {loss }}$ time loss, $t$ total time for perception reaction, deceleration, stopping and acceleration, and $t_{x}$ time required for no intersection scenario.

\subsubsection{Calculation of fuel consumption and GHG emission}

After the construction of the expressway and providing access to the people for general use, $58 \%$ of the vehicular traffic will share the expressway and the rest $42 \%$ will remain on the existing national highway (Ministry of Road Transport and Bridges (MoRTB) 2015a). Fuel consumption (Eq. 19) has been calculated for the vehicles plying on the existing $\mathrm{NH} 1$ and then fuel savings have been computed for the vehicles using the newly constructed expressway. For the sake of the study, two-wheeler motorcycle and three-wheeler scooter have been excluded for the expressway since they are used for short-distance movement. Every intersection induces unnecessary fuel burn and excess gas emission. Analysis of this study has considered driving condition maneuvers (perception reaction, deceleration, complete acceleration, acceleration, and cruise) and vehicular emission estimation (Eq. 20). Emission occurring from vehicle idling is different for electronic fuel ignition (EFI, Model Year 1989-2005) and mechanical fuel ignition (MFI, Model Year 1969-1994) systems (Eq. 21). Khan et al. (2006) reported that idling emission from the vehicles with EFI system emits $20 \mathrm{~g} / \mathrm{h}$ of $\mathrm{CO}, 6 \mathrm{~g} / \mathrm{h}$ of $\mathrm{HC}, 86 \mathrm{~g} / \mathrm{h}$ of $\mathrm{NO}_{X}, 1 \mathrm{~g} / \mathrm{h}$ of PM and $4636 \mathrm{~g} / \mathrm{h}$ of $\mathrm{CO}_{2}$, on the average, and while for MFI system vehicles release $35 \mathrm{~g} / \mathrm{h}$ of $\mathrm{CO}, 23 \mathrm{~g} / \mathrm{h}$ of $\mathrm{HC}, 48 \mathrm{~g} / \mathrm{h}$ of $\mathrm{NO}_{X}, 4 \mathrm{~g} / \mathrm{h}$ of PM and $4484 \mathrm{~g} / \mathrm{h}$ of $\mathrm{CO}_{2}$ on the average. Due to lack of law enforcement and high market demand by the owners, old grumpy registered vehicles are still running on the highways in Bangladesh. In recent years, those vehicles are being replaced by hi-tech and fuel-efficient engine vehicle.

$$
F_{c}=N_{\text {traffic }} \times T_{\mathrm{tt}} \times \frac{v}{F_{e}},
$$

in which $F_{c}$ fuel consumption, $N_{\text {traffic }}$ number/volume of traffic, $T_{\mathrm{tt}}$ travel time, $v$ vehicle's average speed, and $F_{e}$ fuel efficiency.

$$
E(\text { drive cond })=n_{i} \times r(\text { drive cond }) \times t(\text { drive cond }) \times \text { AADT, }
$$


in which $E$ (drive cond) emission of vehicles during different driving condition, $n_{i}$ number of intersection, $r$ (drive cond) emission rate of vehicles during different driving condition, $t$ (drive cond) time required for vehicles during different driving condition, and AADT annual average daily traffic.

$$
E(p, e)=n_{i} \times r(p, e) \times t(\text { idling }) \times \mathrm{AADT},
$$

in which $E(p, e)$ emission of vehicles for different pollutants and engine type, $n_{i}$ number of intersection, $r(p, e)$ emission rate of vehicles for different pollutants and engine type, $t$ (idling) idling time required for vehicles for different driving condition, and AADT annual average daily traffic.

\subsubsection{Calculation of accident cost savings}

The existing national highway is prone to frequent road accident due to mixed traffic. The construction of toll-paid expressway will provide a facility for slow-moving vehicles (SMVs) that is supposed to reduce SMVs' intervention and the possibility of rear on collision. On the other hand, pedestrian access restriction will reduce 'Hit Pedestrian' accident drastically. Traffic on the expressway is not affected by pedestrian or non-motorized traffic, and all interchanges are grade-separated. The cost of road traffic accident (RTA) is estimated as the summation of costs associated during the accident, i.e., (a) victim-related cost (medical cost, lost labor output and pain, grief and sufferings, funeral cost), (b) property damage cost (vehicle damage repair, lost economic output, towing cost), (c) administration cost (police investigation, legal cost, insurance administration and accident spot cleansing), (d) road property damage cost and (e) traffic jam cost.

The estimated cost for each RTA for 2016 has been escalated for 2022 with social discount rate $12 \%$ (inflation $7 \%$ and matching discount $5 \%$ ) while applying for the study. After accident, estimation of road property cost is quiet uncertain and unpredictable since it varies with the accident type and the road environment. For the study purpose, it is assumed that Fatal RTA causes massive destruction (i.e., guardrail and sign-signal failure) and the vehicle eventually derails from the track. Grievous RTA might hit and destroy the sign-signal post and kilometer post and simple RTA would cause damage to the kilometer post. During property damageonly (PDO) accident, a portion of road property might be dismantled. Besides, considering uniform flow, average 1.0-h travel time loss is originated from traffic jam for the post-accident site clearance as there is no alternative to the existing corridor. Current available road accident data is not much reliable. For NH1, the final report prepared by Japan International Cooperation Agency (JICA) (2013) showed 41 accidents per 100 million vehicle-km found in a 2013 report that covered part of the Kanchpur-Daudkandi section. This research has estimated that after project completion the cost of around 600 accidents would be reduced annually.

\subsubsection{Calculation of vehicle operating cost and travel time cost}

The study attempts to estimate vehicle operating cost (VOC) and travel time cost (TTC) due to the lost time at the intersections. VOC includes vehicle and spare 
motor parts purchase cost, fuel and lubricant cost, wages of operators/crews, vehicle maintenance cost, annual overhead cost, etc. While TTC is conceptualized based around that time spent during travelling has an 'opportunity cost' and could be applied in an alternative activity that may produce significant utility or benefit in terms of monetary value. TTC is estimated both for road users and freight consignments through average wage approach survey. For each vehicle type, the number of the travellers in work time (WT) and non-work time (NWT) is assessed. TTC for WT considers the wage rate and for NWT 35\% of the wage rate (Transport Research Laboratory, UK). This study has quoted unit rate of VOC and TTC from RHD Road User Cost Report 2016-2017 report to estimate the total VOC and TTC savings for the loss time savings at the intersections.

\subsubsection{Calculation of economic indicators}

The future value analysis estimates the value of an asset at a specific date. We calculated the future value of project at the end of $n$ years as

$$
\sum_{n=1}^{N} \mathrm{FV}=\sum_{n=1}^{N} \mathrm{PV} \times(1+i)^{n}
$$

where $\mathrm{FV}_{n}$ future value of project at the end of $n$ years, PV present value, $i$ interest rate on government bond, and $n$ number of years in the future.

Benefit-cost ratio (BCR) was calculated as

$$
\mathrm{BCR}=\frac{\text { Total benefit }}{\text { Total cost }}
$$

Net present value (NPV) is the difference between the present value of cash inflows and the present value of cash outflows over a period of time.

$$
\mathrm{NPV}=\sum_{n=1}^{N} \frac{C_{\mathrm{t}}}{(1+i)^{n}}-C_{\mathrm{o}},
$$

where $C_{\mathrm{t}}$ net cash inflow during the period n or present value of benefit, $C_{\mathrm{o}}$ total initial investment costs or present value of cost, $i$ discount rate, and $n$ number of time periods.

Internal rate of return (IRR) is a discount rate that makes net present value (NPV) of all cash flows of a particular project from equal to zero. We used the general formula for the calculation as follows:

$$
0=\sum_{n=1}^{N} \frac{C_{\mathrm{t}}}{(1+i)^{n}}-C_{\mathrm{o}}
$$

in which $C_{\mathrm{t}}$ net cash inflow during the period $\mathrm{n}$ or present value of benefit, $C_{\mathrm{o}}$ total initial investment costs or present value of cost, $i$ discount rate, and $n$ number of time periods. 


\section{Results and discussion}

\subsection{Loss time and fuel savings}

Frequent interventions on the highways reduce the average speed of the vehicle. Asian Development Bank (ADB) (2012) reports the average speed of the vehicle fleet on this highway to be $35-40 \mathrm{kmph}$. At no project situation, the present traffic growth will be beyond the capacity of the corridor during 2022 and the average velocity is supposed to be remarkably low. Based on the four-legged intersection, the study observed $54.0 \mathrm{~s}$ green time out of $120.0 \mathrm{~s}$ cycle time for signal at an intersection (Wright 1995). However, while running on the existing highway in 2022 , a vehicle (assuming average speed is $30.0 \mathrm{kmph}$ ) would require on an average $71.59 \mathrm{~s}(0.0199 \mathrm{~h})$ more against a non-signalized intersection due to perception reaction time $(2.5 \mathrm{~s}$, AASHTO recommendation), deceleration time $(2.83 \mathrm{~s})$ (Eq. 1), stopping time (66.0 s) (Eq. 6), congestion loss time (2.78 s) (Eq. 12) and acceleration time (2.78 s) (Eq. 13). The time lag is shown in Fig. 4. When there are frequent intersections, the delay becomes more crucial for a busy highway that eventually reduces the roadway's desired Level of Services (LOS). After the expressway project is finished, the time loss would be $74.07 \mathrm{~s}$ for those vehicles (assuming average speed is $60.0 \mathrm{kmph}$ ) which would still be using the current NH1. But the total travel time loss would be less than the project picture. The study also estimates that the average velocity of the vehicle is directly proportional to the loss time (Fig. 5).

For the projected traffic growth in 2022 on this corridor (mentioned in Sect. 3.1), the launching of the expressway would result in an estimated fuel loss reduction of 260.39 thousand liters of petrol (7.84\%) and 4989.68 thousand liters of diesel (11.97\%) for the vehicles would still be using the existing national highway (Fig. 6). The amount of fuel savings (5942.15 thousand liters of petrol and 77,323.20 thousand liters of diesel) will be an outcome for the vehicles which will be using the expressway then (Table 4). These consumption amounts are very high since the fuel efficiency data (collected from RHD Road User Cost 2016-2017) are not updated and most of the older vehicles plying on the highway are less fuel efficient.

Fig. 4 Distance-time graph

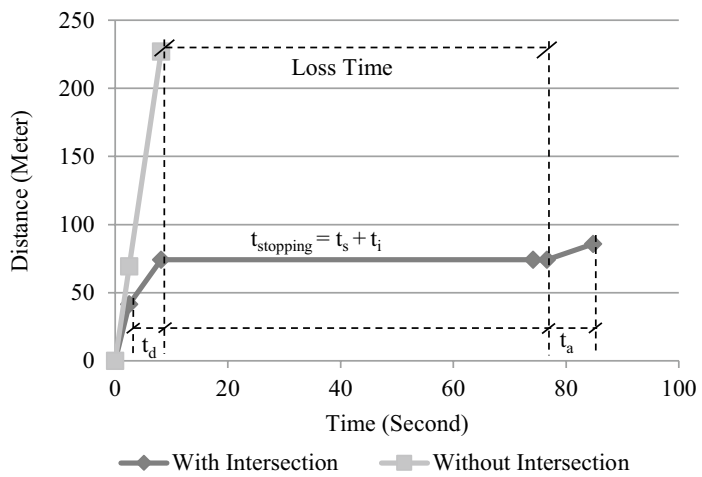


Fig. 5 Relation of vehicle speed with time loss at the intersection

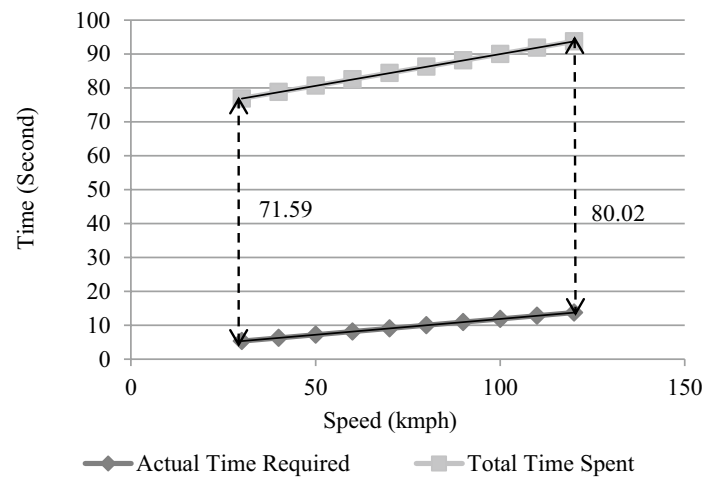

Fig. 6 Fuel loss reduction after construction of the expressway

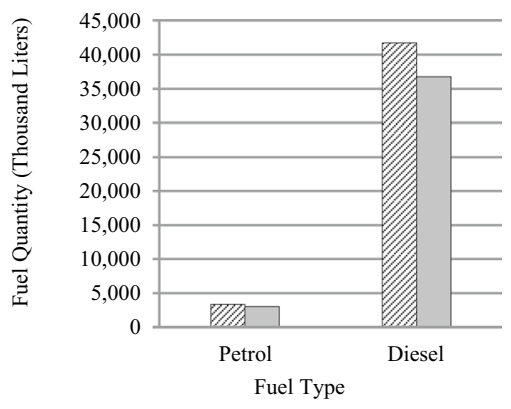

\% Without Project $\square$ With Project

Table 4 Estimation of fuel cost savings during the year 2022

\begin{tabular}{|c|c|c|c|c|c|c|}
\hline \multirow{2}{*}{$\begin{array}{l}\text { Traffic scenario } \\
\text { (AADT) }\end{array}$} & \multicolumn{2}{|l|}{ Petrol } & \multicolumn{2}{|l|}{ Diesel } & \multicolumn{2}{|l|}{$\operatorname{Cost}^{b}$} \\
\hline & Quantity & Unit price $^{a}$ & Quantity & Unit price $^{\mathrm{a}}$ & Loss amount & Savings \\
\hline Veh/day & Thousand liter & BDT/liter & Thousand liter & BDT/liter & Million USD & Million USD \\
\hline $\begin{array}{l}\text { Without pro- } \\
\text { ject }(27,334)\end{array}$ & 3319.43 & 86.00 & $41,698.50$ & 65.00 & 37.45 & \\
\hline $\begin{array}{l}\text { With project } \\
\text { (vehicle } \\
\text { using } \mathrm{NH} 1 \text {, } \\
\text { 13,202) }\end{array}$ & 3059.04 & 86.00 & $36,708.82$ & 65.00 & 33.11 & 4.33 \\
\hline $\begin{array}{l}\text { With project } \\
\text { (vehicle } \\
\text { diverted to } \\
\text { Expressway, } \\
\text { 14,132) }\end{array}$ & 5942.15 & 86.00 & $77,323.20$ & 65.00 & & 69.21 \\
\hline Total & & & & & & 73.55 \\
\hline
\end{tabular}

${ }^{\text {a }}$ Source: Bangladesh Petroleum Corporation (BPC) 2017; price effective from 24 April 2016

${ }^{\mathrm{b}}$ Rate conversion: 1.00 USD =79.98 BDT (average during 1 January 2017 to 31 December 2017) 


\subsection{GHG emission savings}

As mentioned in Sect. 2.3, GHG emission depends on multifarious factors (driving condition distinction, vehicle idling, type of fuel used, type of engine, etc.). This study has considered driving condition variations and vehicle idling for estimating the approximate GHG discharge. Since there are more interventions in the existing highway, driving behavior changes frequently and rather abruptly. In the expressway, the vehicle experiences optimum velocity without interferences that affect vehicular emission. For any intersection, the study estimates that different driving conditions (acceleration, deceleration, cruise, and idle) affect $\mathrm{CO}, \mathrm{NO}$ and $\mathrm{HC}$ emission reduction by $17.18 \%, 8.04 \%$ and $34.43 \%$, respectively (Table 5, Fig. 7).

For the sake of calculating the idling emission from different engines, it is supposed that, in $2022,90.37 \%$ vehicles (mostly medium and heavy) running on the highways will have electronic fuel ignition (EFI) engine and $9.63 \%$ vehicles will have mechanical fuel ignition (MFI) engine. Idling emission time is the summation of completely stopping time and incremental delay at the intersection during the 'Red Signal'. During idling, emissions of carbon oxides (CO), hydrocarbon (HC), nitrogen oxides $(\mathrm{NOx})$, particulate matter $\left(\mathrm{PM}_{10}\right)$ and carbon dioxides $\left(\mathrm{CO}_{2}\right)$ have been computed for both EFI and MFI engines. The idling emission of $\mathrm{CO}, \mathrm{HC}, \mathrm{NOx}$ and PM is estimated as 147.17 ton/year, 52.41 ton/year, 565.08 ton/year and 8.84 ton/year, respectively, when the project is non-operational. After completion of the project, the idling emission of $\mathrm{CO}, \mathrm{HC}, \mathrm{NOx}$ and PM are diminished to $70.46 \mathrm{ton} /$ year, 24.61 ton/year, 274.51 ton/year and 4.15 ton/year, respectively (Table 6).

As one of the major 'Heat-trapping' gases, $\mathrm{CO}_{2}$ plays a significant role in global warming. In business-as-usual case, total $\mathrm{CO}_{2}$ emission from both MFI and EFI engine is approximated to be 31,715.17 ton/year and 15,324.56 ton/year when the project is non-operational and functional in full swing, respectively. Table 6 illustrates that after the project, $\mathrm{CO}_{2}$ emission reduces by $51.68 \%$. The sharp and visible change in different costs of $\mathrm{CO}, \mathrm{NOx}, \mathrm{PM}$ and $\mathrm{CO}_{2}$ emission has been estimated in two case scenarios, which are the presence and the absence of the project (Table 6). Both the driving condition and the vehicle idling at the intersection are seemed to be key aspects that cause the fluctuation in fuel consumption and emission in this study, but the number of heavy-duty vehicles is very high in this corridor and thus idling emission is influenced tremendously. The study has focused on idling emission as the foremost factor for emission.

\subsection{Accident cost savings, vehicle operating cost and travel time cost savings}

The features of the expressway are expected to reduce the number of road accident as per international experience (Ministry of Road Transport and Bridges (MoRTB) 2015a). The study has calculated that around 600 accidents will be reduced per annum. The costs of human loss, property loss, vehicle loss has been retrieved from RHD Road User Cost Report 2016-2017 and the monetary value has seen escalated from 2016 to 2022 after applying 12\% interest rate per year. The road property 


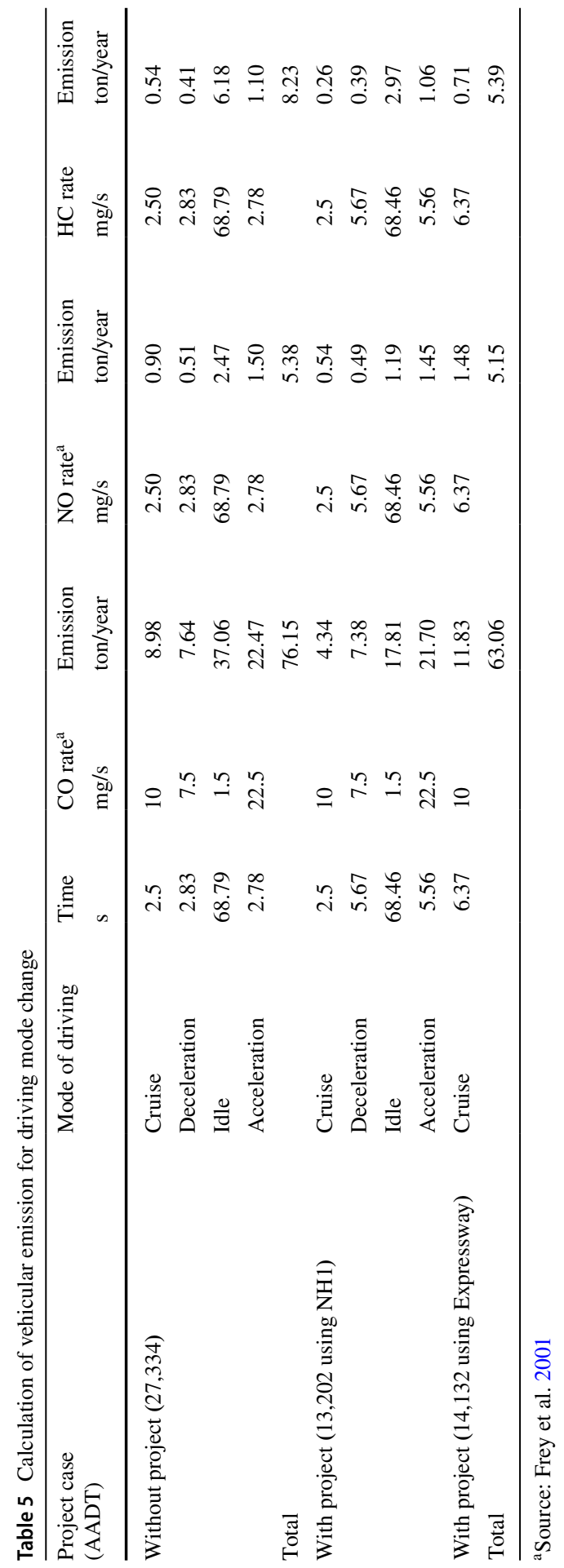


Fig. 7 Effect of driving condition on emission after expressway construction

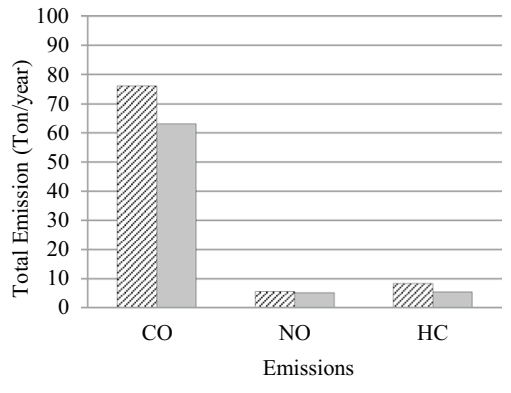

Without Project $\square$ With Project

Table 6 Estimation of social cost of emission during year 2022

\begin{tabular}{lcrcll}
\hline Emissions & $\begin{array}{l}\text { Without project } \\
\text { ton/year }\end{array}$ & $\begin{array}{l}\text { With project } \\
\text { ton/year }\end{array}$ & $\begin{array}{l}\text { Production reduction } \\
\text { ton/year }\end{array}$ & $\begin{array}{l}\text { Social cost } \\
\text { USD/ton }\end{array}$ & $\begin{array}{l}\text { Cost savings } \\
\text { Million USD/year }\end{array}$ \\
\hline $\mathrm{CO}$ & 147.17 & 70.46 & 76.71 & $1.96^{\mathrm{a}}$ & 0.015 \\
$\mathrm{HC}$ & 52.41 & 24.61 & 27.8 & - & - \\
$\mathrm{NO}_{x}$ & 565.08 & 274.51 & 290.57 & $256.09^{\mathrm{b}}$ & 0.074 \\
$\mathrm{PM}$ & 8.84 & 4.15 & 4.69 & $7799.33^{\mathrm{a}}$ & 0.037 \\
$\mathrm{CO}_{2}$ & $31,715.17$ & $15,324.56$ & $16,390.61$ & $59.00^{\mathrm{c}}$ & 0.97 \\
Total & & & & & 1.096 \\
\hline
\end{tabular}

a Source: Rabl et al. 1998

${ }^{\mathrm{b}}$ Source: Pearce 1993

${ }^{\mathrm{c}}$ Source: Golub and Golub 2016

damage cost is estimated for repairing or constructing different road components after the accident and the cost is adjusted for 2022. The study also estimates the cost of travel time loss occurring from post-accident site clearance. Summing up all the evident three types of costs, the study summarizes different road accident costs in terms of different accident severity level, i.e., 0.13707 thousand USD per Fatal RTA (road traffic accident), 0.01949 thousand USD per Grievous RTA, 0.01616 thousand USD per simple RTA and 0.01327 thousand USD per property damaged only (PDO) RTA (Table 7). The accident cost savings would be 16.19 million USD annually (Table 8). The intersection replacement will reduce total journey time $0.781 \mathrm{~h} /$ vehicle for the expressway consumers. Vehicle operating cost (VOC) and travel time cost (TTC) have been calculated for the vehicles which will be using the expressway. In year 2022, for the projected traffic VOC savings is approximated to be 1.86 million USD (Table 9). Travel time cost, computed for 2022, is 55.9 million USD (Table 10).

\subsection{Estimation of toll collection}

Roads and Highways Department (RHD) has considered 7\% inflation rate and proposed toll for the expressway during the fiscal year 2022-2023 for different vehicles 
Table 7 Calculation of unit accident cost during year 2022

\begin{tabular}{|c|c|c|c|c|c|}
\hline \multirow[t]{2}{*}{ Accident type } & Human loss, property & \multirow{2}{*}{$\begin{array}{l}\text { Road property } \\
\text { damage cost } \\
\text { b }\end{array}$} & \multirow[t]{2}{*}{ TTC loss } & \multicolumn{2}{|l|}{ Unit cost } \\
\hline & Thousand BDT/accident & & & \multicolumn{2}{|c|}{$\begin{array}{l}\text { Million USD/acci- } \\
\text { dent }^{c}\end{array}$} \\
\hline Fatal RTA & 9847.40 & 69.83 & 1048.49 & $10,965.72$ & 0.13707 \\
\hline Grievous RTA & 469.77 & 41.17 & 1048.49 & 1559.43 & 0.01949 \\
\hline Simple RTA & 225.02 & 19.12 & 1048.49 & 1292.63 & 0.01616 \\
\hline Property damage only & 13.22 & 0 & 1048.49 & 1061.71 & 0.01327 \\
\hline
\end{tabular}

a Source: Ministry of Road Transport and Bridges (MoRTB) 2017 and the author has calculated Unit Cost

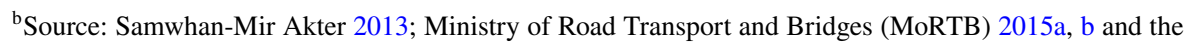
author has calculated Unit Cost

${ }^{\mathrm{c}}$ Rate conversion: 1.00 USD $=79.98$ BDT (average during 1 January 2017 to 31 December 2017)

Table 8 Estimation of accident cost savings during the year 2022

\begin{tabular}{llll}
\hline Accident type & $\begin{array}{l}\text { Unit cost } \\
\text { Million USD/accident }\end{array}$ & $\begin{array}{l}\text { Accident reduced } \\
\text { Number/year }\end{array}$ & $\begin{array}{l}\text { Cost savings } \\
\text { Million USD/year }\end{array}$ \\
\hline Fatal RTA & 0.13707 & 48 & 6.58 \\
Grievous RTA & 0.01949 & 312 & 6.08 \\
Simple RTA & 0.01616 & 120 & 1.94 \\
Property damage only & 0.01327 & 120 & 1.59 \\
$\quad$ PDO & & 600 & 16.19 \\
Total & & & \\
\hline
\end{tabular}

based on the Toll Policy 2014. The data are used in the study to estimate the amount of total toll generated annually for the projected traffic. The Toll Policy, 2014 mentioned the revision of toll policy after 3 years. While calculating the toll for the next years after 2022, a common flat inflation rate is applied only. The amount of toll generated is 154.24 for the projected traffic during fiscal year 2022 (Table 11). The survey conducted by RHD explorers a portion of total vehicles (mostly trucks) using the toll bridges on this corridor was toll free. These vehicles were used to carry goods for different Government financed development works. For transporting by the expressway, these vehicles are also taken under toll collection.

\subsection{Economic viability based on environmental and economic aspects}

The construction period of the project is scheduled for 4 years (fiscal year 2017-2021) and maintenance (routine and periodic) period is considered as 30 years (fiscal year 2022-2051). The discounted present value (for year 2022) of construction and maintenance cost, fuel loss savings, accident cost savings, vehicle operating cost savings, travel time cost savings and toll collection have been summarized for the projected traffic growth during 2022 (after the construction is scheduled to be 
Table 9 Calculation of vehicle operating cost savings during the year 2022

\begin{tabular}{|c|c|c|c|c|c|c|}
\hline \multirow[t]{2}{*}{ Vehicle mode } & \multirow{2}{*}{$\begin{array}{l}\text { AADT } \\
\text { Veh/year }\end{array}$} & \multirow{2}{*}{$\begin{array}{l}\text { AADT after } \\
\text { expressway } \\
\text { diversion } \\
\text { Veh/year }\end{array}$} & \multirow{2}{*}{$\begin{array}{l}\text { Total time loss } \\
\text { h/Veh }\end{array}$} & \multirow{2}{*}{$\begin{array}{l}\text { Vehicle }^{\mathrm{a}} \\
\text { BDT/h }\end{array}$} & \multicolumn{2}{|l|}{ Cost savings } \\
\hline & & & & & $\begin{array}{l}\text { Thousand BDT/ } \\
\text { year }\end{array}$ & $\begin{array}{l}\text { Million } \\
\text { USD/ } \\
\text { year }\end{array}$ \\
\hline Car/jeep & $1,477,601$ & 857,009 & 0.781 & 37.37 & $25,019.03$ & \\
\hline Micro/pickup & $1,804,848$ & $1,046,812$ & 0.781 & 35.83 & $29,300.68$ & \\
\hline Mini bus & 728,325 & 422,428 & 0.781 & 25.24 & 8329.22 & \\
\hline Bus & 838,072 & 486,082 & & & & \\
\hline AC bus $30 \%$ & & 145,825 & 0.781 & 48.08 & 5477.18 & \\
\hline Chair coach $30 \%$ & & 145,825 & 0.781 & 48.08 & 5477.18 & \\
\hline Ordinary L $40 \%$ & & 194,433 & 0.781 & 48.08 & 7302.91 & \\
\hline Truck & $3,809,237$ & $2,209,358$ & & & & \\
\hline Small truck $40 \%$ & & 883,743 & 0.781 & 29.99 & $20,704.50$ & \\
\hline $\begin{array}{l}\text { Medium truck } \\
60 \%\end{array}$ & & $1,325,615$ & 0.781 & 39.28 & $40,677.19$ & \\
\hline $\begin{array}{l}\text { Large truck/ } \\
\text { trailer }\end{array}$ & 234,461 & 135,987 & 0.781 & 57.73 & 6132.84 & \\
\hline Total & & & & & $148,420.76$ & 1.86 \\
\hline
\end{tabular}

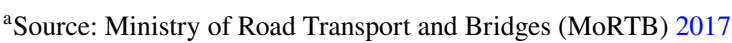

finished) to 2051 in Table 12. The estimated net present value (NPV) is 762.34 million USD and benefit-cost ratio (BCR) is 1.23 . The undiscounted present value of construction and maintenance cost, fuel loss savings, accident cost savings, vehicle operating cost savings, travel time cost savings and toll collection have been estimated for the traffic progressively increased growth from 2022 (after the construction is scheduled to be finished) to 2051. For undiscounted cost and benefit, the economic internal rate of return (EIRR) is found to be $18.27 \%$ (Table 13).

\subsection{Discussion}

The result of this study unearths that the vehicle plying on the existing national highway will result in travel time loss at the intersections. And with the increment of vehicle number, the loss time would be even higher. Consequently, situations of traffic stagnation will occur which will lead to the failure of the network. This study throws some lights on the fact that the expressway construction will minimize travel time loss at the intersections on the existing national highway. Replacing the intersections, this project will prohibit vehicular intervention along the highway that will reduce total travel time and vehicle operating cost. Travel time cost and vehicle operating cost savings, at the end of the day, add the external economies or benefit to the project. Travel time reduction improves transport reliability and creates additional value ( $\mathrm{Li}$ et al. 2010). Less route uncertainty makes travelers and freight 
Table 10 Calculation of travel time cost savings during the year 2022

\begin{tabular}{|c|c|c|c|c|c|c|}
\hline \multirow[t]{2}{*}{ Vehicle mode } & \multirow{2}{*}{$\begin{array}{l}\text { AADT } \\
\text { Veh/year }\end{array}$} & \multirow{2}{*}{$\begin{array}{l}\text { AADT after } \\
\text { expressway } \\
\text { diversion } \\
\text { Veh/year }\end{array}$} & \multirow{2}{*}{$\begin{array}{l}\text { Total time loss } \\
\text { h/Veh }\end{array}$} & \multirow{2}{*}{$\begin{array}{l}\text { Vehicle }^{b} \\
\text { BDT/h }\end{array}$} & \multicolumn{2}{|l|}{ Cost savings } \\
\hline & & & & & $\begin{array}{l}\text { Thousand } \\
\text { BDT/year }\end{array}$ & $\begin{array}{l}\text { Million USD/ } \\
\text { year }\end{array}$ \\
\hline Car/jeep & $1,477,601$ & 857,009 & 0.781 & 390 & $261,103.09$ & \\
\hline Micro/pickup & $1,804,848$ & $1,046,812$ & 0.781 & 749 & $612,509.37$ & \\
\hline Mini bus & 728,325 & 422,428 & 0.781 & 1803 & $594,991.74$ & \\
\hline Bus & 838,072 & 486,082 & & & & \\
\hline AC bus $30 \%$ & & 145,825 & 0.781 & 3961 & $451,229.76$ & \\
\hline $\begin{array}{l}\text { Chair coach } \\
30 \%\end{array}$ & & 145,825 & 0.781 & 3024 & $344,488.46$ & \\
\hline $\begin{array}{l}\text { Ordinary L } \\
40 \%\end{array}$ & & 194,433 & 0.781 & 2280 & $346,311.15$ & \\
\hline Truck & $3,809,237$ & $2,209,358$ & & & & \\
\hline $\begin{array}{l}\text { Small truck } \\
40 \%\end{array}$ & & 883,743 & 0.781 & 793.4 & $547,747.58$ & \\
\hline $\begin{array}{l}\text { Medium truck } \\
60 \%\end{array}$ & & $1,325,615$ & 0.781 & 1088.25 & $1126,959.22$ & \\
\hline $\begin{array}{l}\text { Large truck/ } \\
\text { trailer }\end{array}$ & 234,461 & 135,987 & 0.781 & 1756.88 & $186,638.96$ & \\
\hline Total & & & & & $4,471,979.36$ & 55.90 \\
\hline
\end{tabular}

a Source: Ministry of Road Transport and Bridges (MoRTB) 2017

Table 11 Calculation of toll collection for projected traffic during the year 2022

\begin{tabular}{|c|c|c|c|c|c|c|}
\hline \multirow[t]{2}{*}{ Vehicle mode } & $\begin{array}{l}\text { Number of } \\
\text { vehicle }\end{array}$ & $\begin{array}{l}\text { AADT after } \\
\text { expressway } \\
\text { diversion }\end{array}$ & Toll rate ${ }^{a}$ & Distance & Toll collected & Toll collected ${ }^{b}$ \\
\hline & Veh/year & Veh/year & BDT/km & $\mathrm{km}$ & $\begin{array}{l}\text { Million BDT/ } \\
\text { year }\end{array}$ & $\begin{array}{l}\text { Million USD/ } \\
\text { year }\end{array}$ \\
\hline Car/jeep & $1,477,601$ & 857,009 & 3.00 & 217.7 & 559.71 & \\
\hline Micro/pickup & $1,804,848$ & $1,046,812$ & 8.00 & 217.7 & 1823.13 & \\
\hline Minibus & 728,325 & 422,428 & 12.00 & 217.7 & 1103.55 & \\
\hline Bus & 839,070 & 486,661 & 17.00 & 217.7 & 1801.08 & \\
\hline Truck & $3,006,085$ & $1,743,529$ & 13.00 & 217.7 & 4934.36 & \\
\hline Trailer & 234,461 & 135,987 & 27.00 & 217.7 & 799.32 & \\
\hline Toll free & 803,152 & 465,828 & 13.00 & 217.7 & 1318.34 & \\
\hline Total & & & & & $12,339.50$ & 154.24 \\
\hline
\end{tabular}

${ }^{\text {a }}$ Source: Ministry of Communications (MoC) 2014

${ }^{\mathrm{b}}$ Rate conversion: 1.00 USD $=79.98$ BDT (average during 01.01. 2017-31.12.2017) 
Table 12 Summary of present value of cost and benefit

\begin{tabular}{lll}
\hline Components & $\begin{array}{l}\text { Cost } \\
\text { Million USD }\end{array}$ & $\begin{array}{l}\text { Benefit } \\
\text { Million USD }\end{array}$ \\
\hline Construction (2017-2021) & 3260.00 & \\
Maintenance (2022-2051) & 27.77 & \\
Fuel cost saving & & 595.10 \\
GHG emission savings & & 8.73 \\
Accident cost saving & & 82.88 \\
Vehicle operating cost & & 14.18 \\
Travel time cost & & 427.29 \\
Toll collection (2022-2051) & & 2921.93 \\
Total & 3287.77 & 4050.11 \\
\hline
\end{tabular}

Table 13 Summary of economic analysis

\begin{tabular}{lll}
\hline Components & Unit & Value \\
\hline Project construction period & Year & 4 \\
Project maintenance period & Year & 30 \\
Present value of cost & Million USD & 3287.77 \\
Net present value (NPV) & Million USD & 762.34 \\
Benefit-cost ratio (BCR) & & 1.23 \\
Economic internal rate of return (EIRR) & $\%$ & 18.27 \\
\hline
\end{tabular}

operators adjust their trip scheduling as per demand and reduce potential contingency cost of delay that has a head-on impact on the service cost and product price at the market (CIE, 2006).

One of the particular outcomes of the study is to evaluate the comparison in the reduction of excess fuel burn for the vehicles that are losing time at the intersections while using NH1 and amount of fuel savings generate after the expressway construction. Reduction in fuel consumption in this sector will save unnecessary foreign currency expenditure which could be invested in the more potential sectors according to necessity. Simultaneously, it will augment the foreign currency reserve and contribute to the GDP growth. As a result of reduced fuel consumption, GHG emission decreases substantially. GHG emission during vehicle idling has noteworthy impacts on heavy vehicles. Since the number of heavy vehicles on this corridor is gigantic, change in emission has been noticed in case of heavy-duty vehicles like coaster/mini bus, bus, truck, trailer, etc. The study estimates the social cost of GHG emission reduction for engine type variations (EFI and $\mathrm{MFI}$ ). The social cost reduction of vehicular emissions adds potential environmental benefit to the new proposed project. From Bangladesh's perspective, most of the economic activities are established within the close proximity to the highways. The GHG emission reduction will contribute to the health benefit to the residents and economic dwellers near the corridor. It is worth mentioning that the emission reduction will stabilize optimum roadside temperature, improve roadway environment and contribute less in global warming. 
Due to several interventions and huge mixed traffic, Dhaka-Chittagong National Highway is very much susceptible to frequent road accidents. International practice has shown that access controlled dedicated highway could be a prime initiative to lessen road mishaps or vehicular collisions in this corridor (Ministry of Road Transport and Bridges (MoRTB) 2015a). Since the cost of road accident is associated with several identities including injured person and caregiver, medical services, road agency, insurance company, post-injury care center and traffic system, the cost savings will be reflected at all those sectors as well as will create a rigorous leverage on the developing economy like Bangladesh.

Moreover, this toll generated expressway will contribute to the Government's revenue earning (internal economies or benefit) annually up to a certain project life span. Needless to say, investment in such a giant project demands an assurance of economic and financial returns. The present toll policy applied to the projected traffic will be able to ensure consumer surplus and investment returns. As a limitation of the research, the study was confined within the features associated with replacing the intersections and did not consider all the potential aspects of the corridor. But still, the net benefit is 762.34 million USD and BCR is more than 1. The EIRR for undiscounted cost and benefit is estimated to be close to $18.27 \%$. The present cost of capital is roughly $12 \%$ (assumed for this project and period) for Bangladesh. Since the EIRR is more than the cost of capital, the project is very much feasible for investment (World Bank 1998).

Greater Mekong Sub-region East-West Economic Corridor Eindu to Kawkareik Road Improvement Project (Myanmar), which was assessed by ADB also considered similar benefit factors mentioned above. The EIRR of the project was $19.5 \%$ and BCR was 1.299. In the preliminary financial analysis of JICA-financed Bangalore-Chennai Expressway $(270 \mathrm{~km})$, the highest priority expressway network in India under the National Highways Authority of India (NHAI), EIRR was $24.5 \%$ (Ministry of Economy, Trade and Industry 2012). Economic study of these two projects has similarity with the proposed Dhaka-Chittagong Expressway.

\section{Conclusion}

The feasibility study (Ministry of Road Transport and Bridges (MoRTB) 2015a, b) summarizes a multi-criteria analysis (MCA) among the five alternative options that cover technical quality assessment, social impact assessment, environmental impact and financial parameters to a great extent. Since the feasibility study had a wide range of scope of work, it explored rigorously potential impacts associated with the new construction project. The social impact assessment analysis was very much prime in that respect. In this study, we calculated the environmental impact cost in various perspectives. Cost savings from less fuel burning and corresponding reduction in GHG emission were the major findings of this study. While doing this, we have considered the fuel use practice and variation in engine used in vehicles in Bangladesh that are very much identical compared to the feasibility study. We estimated the cost of emission reduction. These fuel cost savings and emission cost savings are unique in this study and contribute to the benefit of Dhaka-Chittagong 
Expressway Construction Project. Except for the feasibility study, we considered additional parameters (traffic congestion loss time cost, repair cost of road structures) to calculate the accident cost savings from the new project. These particular changes have made this study unique and identical to the feasibility study.

The economic impacts of transportation projects are perplexed enough to measure precisely. Though the conceptual framework to obtain the benefits of transportation projects is very straightforward, it cannot always be measured by the market value of the services rendered. Indirect approaches ought to be taken to assess them. The evaluation of transport projects demands multi-criteria analysis (MCA) for comparing both the statuses before and after the project. Owing to the complex nature of transport projects, every study associated with this sector requires considerable assumption and value judgment. The utmost goal of most of the transport projects is to provide comfort, convenience, and reliability of service within the least of transport costs to the users. On the other hand, the Government's investment decision points straight towards the stimulation of economic and infrastructural development and indubitably, overall environmental betterment. In this dubious situation, economic and environmental sustainability together poses a challenge to investment.

Expressway bypasses intersections and reduces potentials interferences at the intersection. The study proved that a vehicle plying on the highways with frequent interventions required more travel time (74.07 s) compared to a vehicle plying on the freeways. Travel time controls several factors like vehicle operating costs, fuel consumption, GHG emission, etc. In several developing countries this is recognizable that the passenger and commercial transportation system has a mutual correlation with the development indicators. With smooth and swift connectivity and accessibility, more job sector is created, market flourishes and trade is enhanced rapidly which eventually contributes to the GDP of the country. In this sense, utilizing the allocated budget for the transport sector by rigorous and inclusive research and analysis in the best possible manner is cardinal to favor the economy at the end of the day.

The target of this specific research was to explore, unravel and exploit the potential significance and boons of the proposed Dhaka-Chittagong Expressway taking environment and economic perspectives on the radar. Despite a few research limitations, the study measures the amount of travel time savings for the projected level of traffic that would be using the expressway. The research outcome concludes with the major quantity of fuel savings that would substantially lessen the wastage of foreign currency to import fuel. Additionally, fuel consumption reduction undoubtedly reduces the vehicular emission in the purlieu of the roadway that reduces roadside temperature and increases visibility. In the study, two different types of emission factors (driving modes and Idling emission) were considered. Changes in driving modes found that after the project finished $\mathrm{CO}, \mathrm{NO}$ and $\mathrm{HC}$ emission would be reduced. The idling emission of $\mathrm{CO}, \mathrm{HC}, \mathrm{NOx}$ and $\mathrm{PM}$ is estimated for MFI and EFI engines. GHG emission reduction (for MFI and EFI engine) would also contribute to cut down likely risks of the carcinogenic diseases born from the roadway environment. The study finally estimates the social cost of GHG emission reduction which is the reduction of negative externalities by compensating vehicular emission which adds value to a sustainable environment. 
When there are intermittent intervals in the highways, the driver becomes more aggressive to cover up the lost time to reach the destination as quickly as possible. Belligerent driving stimulates vehicular emission and sharply engenders wearing and tearing out of engine, brakes, tires, etc., and thus maintenance costs (costs of lubricants, replace motor parts, etc.) increases. Reduction of intersections and interferences effectively slashes travel time and vehicle operating hours to the bone. Generally, in the developing countries, large investment in the flagship project needs to consider various factors of feasibility like cost of capital, financial stability and viability of the investor, assurance of the capital return, interest rates of financial institutions, projected demands functions, etc. With numerous other constraints, the research finds present value of benefit (4050.11 Million USD), present value of cost (3287.77 million USD), net present value (762.34 million USD); benefit-cost ratio (1.23) and economic internal rate of return (18.27\%) are creditworthy in considering environmental and economic dimensions. This research outcome might be implied as a positive tool while taking decision in expressway investment in future. The study finds significant emission reduction that can cause a positive implication on ecology and biodiversity which can be mentioned as the social cost saving for the Sustainable Transport System initiated by the Government. Emission reduction in similar project can be an exemplary model of clean development mechanism for a developing country like Bangladesh and a sustainable project for investment by the industrialized countries.

Last but not least, the study widens up an extended horizon and arena of vision in focusing on the successful implementation of sustainable development goals (SDGs). Going hand in hand with the rapid accessibility by improving links, the project promotes inclusive mobility, resource management, energy efficiency, safety and security, climate risks assessments and enhance the resilience of existing and future infrastructure.

\section{Compliance with ethical standards}

Conflict of interest The authors declare that they have no conflict of interest.

Open Access This article is distributed under the terms of the Creative Commons Attribution 4.0 International License (http://creativecommons.org/licenses/by/4.0/), which permits unrestricted use, distribution, and reproduction in any medium, provided you give appropriate credit to the original author(s) and the source, provide a link to the Creative Commons license, and indicate if changes were made.

\section{References}

Alam JB, Wadud Z, Alam JB, Polak JW (2013) Energy demand and economic consequences of transport policy. Int J Environ Sci Technol 10:1075-1082. https://doi.org/10.1007/s13762-013-0240-1

Asian Development Bank (ADB) (2012) Proposed technical assistance loan people's Republic of Bangladesh: Dhaka-Chittagong Expressway public-private partnership design project. Report and Recommendation of the President to the Board of Director

Bachman WH (1998) A GIS based modal model of automobile exhaust emission. Georgia Institute of Technology, Atlanta, USA 
Bangladesh Economic Zones Authority (BEZA) (2017) Economic zones site. Ihttp://www.beza.gov.bd/ economic-zones-site/. Accessed 10 June 2018

Bangladesh Petroleum Corporation (BPC) (2008) Petroleum products consumption statistics. Bangladesh Petroleum Corporation, Dhaka

Bangladesh Petroleum Corporation (BPC) (2017) Imported petroleum products. http://www.bpc.gov. bd/contactus.php?id=46. Accessed 10 June 2018

Barth M, Norbeck J (1997) NCHRP Project 25-11: the development of a comprehensive modal emission model. In: Proceedings of the Seventh CRC On-Road Vehicle Emissions Workshop, Coordinating Research Council, Atlanta, Georgia, pp 6.53-6.71

Calvert JG, Heywood JB, Sawyer RF, Seinfeld JH (1993) Achieving acceptable air quality: some reflections on controlling vehicle emissions. Science 261(5117):37-45

Climatelinks (2016) Greenhouse-gas-emissions-factsheet: Bangladesh retrieved from https://www. climatelinks.org/sites/default/files/asset/document/GHGEmissionsFactsheetBangladesh4-2816editedrev08-18-2016Clean.pdf. Accessed 10 June 2018

De Vlieger I (1997) On board emission and fuel consumption measurement campaign on petroldriven passenger cars. J Atmos Environ 31(22):3753-3761. https://doi.org/10.1016/S1352 $-2310(97) 00212-4$

De Vlieger I, De Keukeleere D, Kretzschmar J (2000) Environmental effects of driving behaviour and congestion related to passenger cars. J Atmos Environ 34(27):4649-4655. https://doi. org/10.1016/S1352-2310(00)00217-X

Frey H, Rouphail N, Unal A, Colyar J (2001) Emission reduction through better traffic management: an empirical evaluation based upon on-road measurements. Report no. FHWA/NC/2002-001, North Carolina, DoT, USA

Golub A, Golub ES (2016) Cost-benefit analysis of adaptation strategy in Bangladesh. Copenhagen Consensus Center, Tewksbury, USA

Guensler R (1993) Vehicle emission rate and average vehicle operating speeds. Ph.D. dissertation, University of California, Davis, CA

Hoque MM, Mahmud SMS (2015) Road safety engineering challenges in Bangladesh. https://www. researchgate.net/publication/265200689. Accessed 10 June 2018

Japan International Cooperation Agency (JICA) (2013) The Kanchpur, Meghna, Gumti Second Bridges Construction and Existing Bridges Rehabilitation Project. Final Report. Oriental Consultants with Katahira and Engineers International, Dhaka

Khan AS, Clark NN, Thompson GJ, Wayne WS, Gautam MWD (2006) Idle emissions from heavyduty diesel vehicles: review and recent data. J Air Waste Manag Assoc 56(10):1404-1419

Kohno H (2016) Economic effects of public investment an emphasis on Marshallian and monetary external economies, new frontiers in regional science: Asian perspectives, vol 1. Springer, Berlin

LeBlanc DC, Meyer MD, Saunders FM, Mulholland JA (1994) Carbon monoxide emissions from road driving: evidence of emissions due to power enrichment. Transp Res Rec 1444:126-134

Lenzen M (1999) Total requirements of energy and greenhouse gases for Australian transport. Transp Res Part D Transp Environ 4(4):265-290. https://doi.org/10.1016/S1361-9209(99)00009-7

Li Z, Hensher DA, Rose JM (2010) Willingness to pay for travel time reliability in passenger transport: a review and some new empirical evidence. Transp Res Part E Logist Transp Rev 46(3):384-403

Ministry of Communications (MoC) (2005) The Government of Bangladesh. Road User Cost 2004-2005. http://rthd.portal.gov.bd/. Accessed 10 June 2018

Ministry of Communications (MoC) (2014) The Government of Bangladesh. Toll Policy. http://rthd.porta 1.gov.bd/. Accessed 10 June 2018

Ministry of Economy, Trade and Industry (2012) Study on The Bangalore-Chennai Expressway Construction Project in The Republic of India Retrieved from https://www.jetro.go.jp/extimages/jetro /activities/contribution/oda/modelstudy/earthinfra/pdf/h23saitaku01e.pdf. Accessed 10 June 2018

Ministry of Road Transport and Bridges (MoRTB) (2015a) Final report on feasibility study and detailed design under technical assistance for detailed study and Design of Dhaka-Chittagong Expressway on PPP Basis

Ministry of Road Transport and Bridges (MoRTB) (2015b) Ministry of Road Transport and BridgesRHD Schedule of Rates. http://rthd.portal.gov.bd/. Accessed 10 June 2018

Ministry of Road Transport and Bridges (MoRTB) (2017) The Government of Bangladesh. Draft Road User Cost 2016-2017 report Retrieved from Report http://rthd.portal.gov.bd/. Accessed 10 June 2018 
Pearce DW (1993) Economic values and the natural World. The MIT Press, Cambridge, Massachusetts, USA

Pollack A, Heiken JG, Gorse RA (1992) Comparison of remote sensing data and vehicle emission models: the high proportion of emissions from high emitting vehicles. In: Proceedings, 87th Annual Meeting, Air and Waste Management Association, Pittsburgh, PA

Rabl A, Spadaro JV, McGavran PD (1998) Health risks of air pollution from incinerations: a perspective. Waste Manag Res 16:365-388

Rouphail NM, Frey HC, Unal A, Dalton R (2000) ITS integration of realtime emissions and traffic management systems. IDEA Project no. ITS-44, Prepared by North Carolina State University for the IDEA Program, Transportation Research Board, National Research Council, Washington, DC. May 2000

Samwhan-Mir Akter JV (2013) South Asia Sub-regional Economic Cooperation (SASEC) Road Connectivity Project Interim payment certificate No.17, Ministry of Road Transport and Bridges (MoRTB)

Shih R, Sawyer RF (1996) The relation between throttle positioning and emissions. In: Proceedings of the Sixth CRC On-Road Vehicle Emission Workshop, Coordinating Research Council, San Diego, CA, pp 2.41-2.51

Shih R, Fable S, Sawyer RF (1997) Effects of driving behavior on automobile emissions. In: Proceedings of the Seventh CRC On-Road Vehicle Emissions Workshop, Coordinating Research Council, Atlanta, GA, pp 6.115-6.124

Transportation Research Board (TRB) (1995) Expanding metropolitan highways: implications for air quality and energy use, special report 245. Transportation Research Board, Washington, DC

Transportation Research Board (TRB) (2000) Highway capacity manual. Transportation Research Board, Washington, DC

Ullah MA, Hoque MM, Nikraz H (2013) Traffic growth rate and composition of Dhaka-Chittagong Highway (N-1) of Bangladesh: the actual situation. In: Recent Advances in Energy and Environmental Management, pp 201-206

Ullah MA, Nikraz H, Hoque S (2016) Detail assessment on the distribution of vehicular traffic pattern along national highway No.1 (NH-1) of Bangladesh. Int J Transp Logist 16:33-41

World Bank (1998) Handbook on economic analysis of investment operations. Technical Appendix. World Bank, Washington, DC. http://www.worldbank.org/education/economicsed/project/ projwork/Handbook.pdf. Accessed 10 June 2018

Wright PH (1995) Highway engineering, 6th edn. Wiley, Hoboken

Publisher's Note Springer Nature remains neutral with regard to jurisdictional claims in published maps and institutional affiliations.

\section{Affiliations}

\section{Md. Zia Uddin ${ }^{1} \cdot$ Takeshi Mizunoya $^{2}$}

Md. Zia Uddin

zuddin01@gmail.com

1 Graduate School of Life and Environmental Sciences, University of Tsukuba, Tsukuba, Japan

2 Faculty of Life and Environmental Sciences, University of Tsukuba, Tsukuba, Japan 